DOI https://doi.org/10.30525/978-9934-26-073-5-2-9

\title{
ФОРМУВАННЯ МОВНОЇ КОМПЕТЕНЦІЇ В КОНТЕКСТІ ПРОФЕСІЙНОЇ ПІДГОТОВКИ В ЗВО
}

\author{
Бойко Л. П. \\ кандидат філологічних наук, доцент, \\ доиент кафедри української мови \\ Запорізького національного університету \\ Чернова I. B. \\ кандидат філологічних наук, доиент, \\ завідувач кафедри українознавства та загальної мовної підготовки \\ Начіонального університету «Запорізька політехніка» \\ м. Запоріжжя, Україна
}

Наразі комунікативна компетенція сучасного фахівця $є$ однією 3 визначальних характеристик успішної ділової людини. Освітні стандарти підготовки фахівців різних напрямів обов'язково передбачають набуття здобувачами освіти комунікативної компетенції, яка являє собою поєднання мовленнєвої, мовної, дискурсивної, соціокультурної, соціолінгвістичної, стратегічної компетенції, що спонукає до пошуків шляхів ефективної реалізації такої вимоги.

Мовна компетенція, тобто засвоєння лексичних, фонетичних, граматичних та орфографічні норм, є базовою у структурі комунікативної компетенції, а отже, потребує системної, копіткої роботи з формування аналітичних, творчих та практичних навичок. Мова загалом є складником професійної підготовки. 3 огляду на це проблема формування та мотивування до вдосконалення мовної компетенції є актуальною.

Мовна компетенція в загальному розумінні - це знання учасниками комунікації мовного коду та правил його використання [1, с. 398]. Водночас професійна мовна компетенція свідчить про рівень сформованості системи професійних знань, комунікативних умінь і навичок, ціннісних орієнтирів, загальної культури, інтегральних показників культури мовлення, необхідних для якісної професійної підготовки.

В окресленому контексті вагома роль відводиться викладачам мовних курсів, адже попри те, що становлення професійного мовлення реалізується в міждисциплінарних зв'язках, координування цього процесу відбувається саме в мовознавчих курсах. 
Метою дослідження $є$ комплексний підхід до вивчення складників та способів формування мовної компетенції з акцентом на інтерактивні методи навчання та мотивацію як передумову ефективності цього процесу.

Професійну мовну комунікацію в різних аспектах досліджувала низка вітчизняних та зарубіжних вчених, зокрема Ю. Г. Барабаш, Ф. С. Бацевич, Г. Т. Почепцов та ін. $[3,4,5]$, проте методичний та мотиваційний аспекти наразі потребують досконалішого вивчення.

У дидактиці тривалий час навчальний процес трактувався як передача знань, зокрема від викладача-студентові. За таких умов передбачалася активна роль викладача та пасивна роль студента. Наразі із запровадженням компетентнісного підходу в освіті суттєво змінилися й підходи до процесу навчання, яке нині розглядається як спільна діяльність усіх учасників навчального процесу.

Результати навчання у вигляді збагачення, уточнення, активізації словникового запасу, засвоєння мовних норм та навички 3 їх застосування, принципи побудови ефективного висловлювання тощо забезпечуються завдяки використанню на заняттях різних видів і форм роботи, насамперед, інтерактивних методів навчання, що дозволяє перейти від різноманітних вправ до активної розумової діяльності студентів. Такий підхід спонукає до вільного висловлювання власних думок, дозволяє постійно бути в полі уваги учасників навчального процесу та знаходити оптимальні мовні засоби для використання у своїй діяльності.

Виходячи з потреб студентів, враховуючи сучасні реалії та запровадження масового дистанційного навчання в закладах освіти, доцільно максимально використовувати можливості популярних інформаційнокомунікаційних технологій, передусім мобільного навчання. Це дозволить зробити навчальний процес ефективним, гнучким, динамічним i доступним. Тут у нагоді стануть різноманітні популярні онлайн ресурси, а також авторські розробки викладача.

Проте жодна сучасна методика чи харизматичний досвідчений педагог не можуть оминути питання зацікавленості, мотивації самих студентів до мовної освіти.

На початкову етапі потрібно з'ясувати (наприклад, шляхом анкетування): для чого студент підвищує свій мовний рівень; чого бажає досягти, підвищивши рівень володіння мовою; які має слабкі сторони; як, на його думку, можна покращити рівень власної мовної компетентності. Таке опитування дозволяє виробити траєкторію для групи чи окремого студента. Зокрема, значна кількість першокурсників, 
формулюючи бажані результати, називає ефективне спілкування, вміння грамотно формулювати технічне завдання, здатність належним чином представляти та обгрунтовувати результати своє роботи.

3-поміж власних переваг студенти виділяють вільне володіння мовою, знання основних правил та бажання вдосконалювати свої знання. А щодо слабких сторін - невправність у пунктуації та періодичні труднощі у доборі потрібного слова, що призводить до невпевненості чи навіть побоювання висловлюватися перед аудиторією.

Варто зауважити, що вхідний контроль знань та навичок студентів виявляє значно ширше коло проблем. Наприклад, доволі часто трапляються випадки неправильного наголошування слів, неправильне розуміння значення часто вживаних запозичених слів, невміння належним чином обгрунтувати своє судження, вживання калькованих слів та словосполучень тощо.

3 огляду на об'єктивний стан володіння мовою та потребу опертя на базовий рівень підготовки, потрібно у процесі навчання поєднувати традиційні форми роботи 3 інноваційними, постійно апелювати до шкільної програми і окреслювати перспективу в контексті обраної спеціальності.

Отже, правильна мотивація, чітке розуміння поставлених завдань та наполегливість здатні забезпечити удосконалення мовної компетенції.

\section{Література:}

1. Федоренко С. Л. Формування мовної компетенції як основний складник імплементації європейських освітніх стандартів у вивченні іноземної мови. Лінгвокультурний дискурс у парадигмі професійної освіти : зб. матеріалів міжнар. наук.-практ. конф. м. Київ, 5 берез. 2015 р. / редкол. : І. А. Колеснікова (голова) та ін. Київ : КНЕУ, 2015. С. 397-402.

2. Методи та засоби підвищення мовленнєвих компетенцій 3 іноземної мови в практичній діяльності майбутніх економістів : колект. наук. монографія ; за заг. ред. О. В. Керекеши. Одеса : Вид-во «Атлант BOI COIУ», 2017. $147 \mathrm{c}$.

3. Барабаш Ю. Удосконалення іншомовної комунікативної компетенції молодих науковців. Педагогіка і психологія професійної освіти. 2013. №3. С. 91-96. URL: http://nbuv.gov.ua/UJRN/Pippo_ 2013_3_11

4. Бацевич Ф. С. Нариси 3 комунікативної лінгвістики : монографія. Львів : Вид. центр при ЛНУ ім. І. Франка, 2003. 281 с.

5. Почепцов Г.Г. Теорія комунікації. 2-ге вид., доп. Київ : Видавничий центр «Київський університет», 1999. 307 с. 